\title{
Study on Identification and Biology of Okra Mites sp.
}

\author{
Y.T. Jadhav ${ }^{1}$, B.B. Bhosale ${ }^{2}$ and D.P. Barkade ${ }^{3}$ \\ ${ }^{1}$ Department of Agricultural Entomology, Ratnai Agriculture College, \\ Akluj -413101(M.S.), India \\ ${ }^{2}$ Directorate of Extension Education, Vasantrao Naik Marathwada Krishi Vidyapeeth, \\ Parbhani - 431402 (M.S.), India \\ ${ }^{3}$ Department of Agricultural Entomology, Ratnai Agriculture College, \\ Akluj -413101(M.S.), India \\ *Corresponding author
}

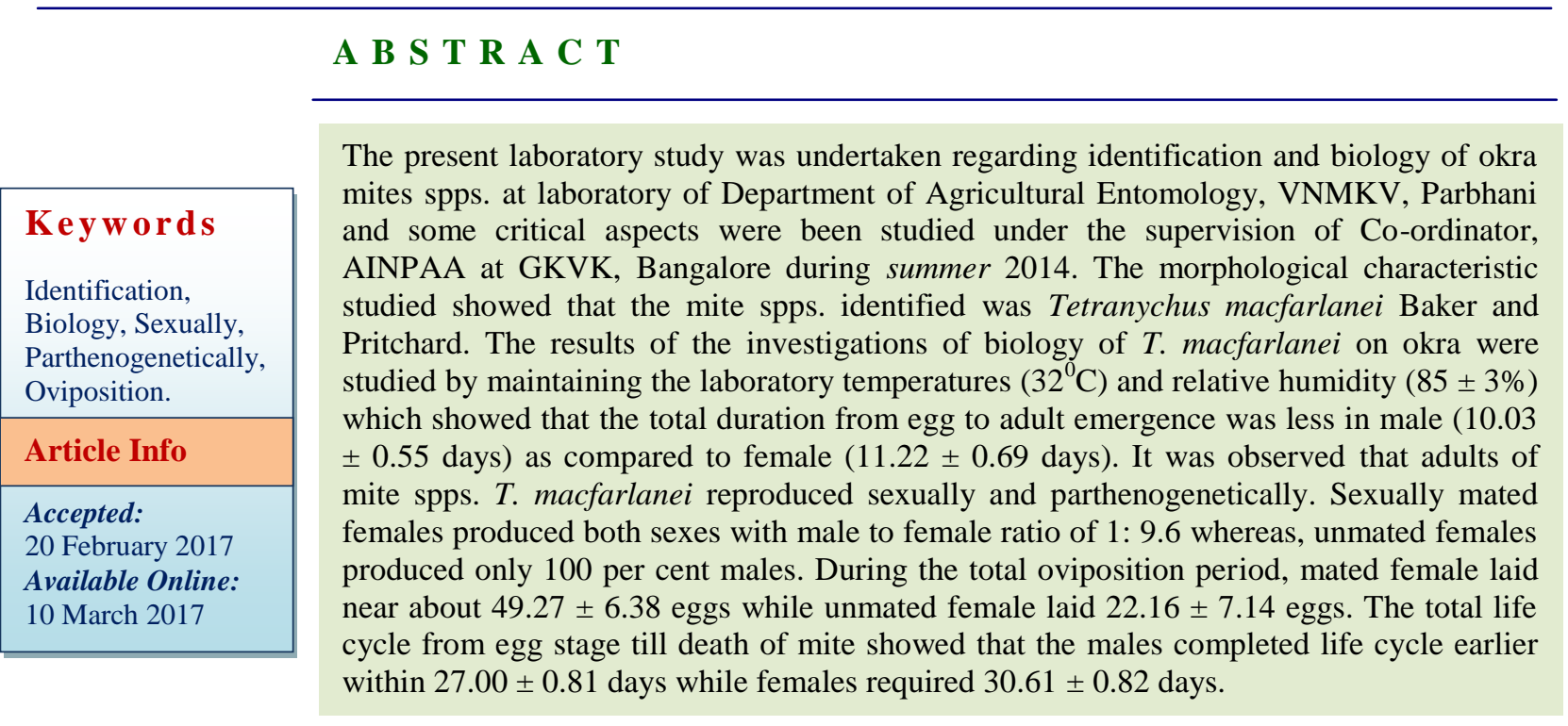

\section{Introduction}

Okra (Abelmoschus esculentus (L.) Moench) commonly known as "Lady's finger" or "Bhendi" is a flowering plant under Malvaceae family having multipurpose crop value which produces high valued edible green pods with good nutritional value and originated from Africa. It is mostly used as a fresh vegetable, also consumed as canned, dehydrated or frozen forms or in culinary preparations, ripe seeds are roasted and used as substitute for coffee, fruits have high medicinal value and are used for catarrhal attacks, fever and irritable stales of genitourinary organs, chronic dysentery and bland mucilage generally in form of soap (Basu and Ghosh, 1943).

India ranks first in okra cultivation and production with an area of 532.64 thousand hectares and production of 6346.40 thousand tonnes along with productivity of $13.14 \mathrm{mt} / \mathrm{ha}$ (Anonymous, 2013). Okra is also known as 
the house of pests due to its two distinct i.e vegetative and fruiting growing stages. As high as 72 species of insects have been recorded on okra. Besides insect pests, several species of mites belonging to the genus Tetranychus causes a loss of 7 to $48 \%$ in okra fruit yield (Srinivasa and Sugeetha, 1999; Kumaran et al., 2007). The two spotted spider mite, Tetranychus urticae Koch was reported as one of the important mite pests of vegetable crops and ornamentals in greenhouses and of several other agricultural outdoor crops (Mondel and Ara, 2006), hence demanding a suitable control measure owing to its wide distribution all over the world on different plant hosts.

The spider mite, Tetranychus cinnabarinus (Biosduval) has assumed the status of major pest and caused 17.46 per cent yield loss in okra (Sarkar et al., 1996). In view of the above facts and scarcity of related information against Tetranychid mites on summer okra, the present investigation were undertaken in laboratory with an objective to identify and study in detail biology of mites (Tetranychus spp.) on okra.

\section{Materials and Methods}

The laboratory study was conducted in the laboratory of Department of Agricultural Entomology, VNMKV, Parbhani during summer 2014. Also some critical aspects regarding identification and biology of mites spps. were been studied under the supervision of Co-ordinator, AINPAA at GKVK, Bangalore.

Maintenance of okra mite culture for taxanomic identification and knowing biology of mites (Tetranychus spp.)

Taxanomic identification of okra mites (Tetranychus spp.)

To know the taxonomic identification of mite sp., large number of infested leaves with mites were collected within small plastic bags knotted with rubber band from the okra variety (Parbhani Kranti) experimental plot conducted at Department of Agricultural Entomology, VNMKV, Parbhani.

The specimen collected in small plastic bags were stored in thermocol box to maintain the inner temperature and secure the specimen from any damage as it required more than 32 hours to reach AINPAA, GKVK, Bangalore where further process regarding taxonomic identification was carried out. Also the purpose of collecting the mite sp. infested leaves was to know if any natural predators or parasitoids are present on the sample leaves which may help for future studies.

\section{Biology of okra mite sps.}

For this laboratory experiment, infested leaves of okra Parbhani Kranti variety by mites sps. were collected from the field and maintained for colonization in a plastic tray $(30 \times 25 \times 6 \mathrm{~cm})$ placed with well moistened synthetic absorbent sponge on which okra leaves were kept in upper surface down position for proper development and laying of eggs and colonizing within 10-15 days . The leaves were changed if turned yellow or dried periodically.

In another plastic trays $(30 \times 25 \times 6 \mathrm{~cm}) 20$ petric plates in proportion of 5 petric plates each tray were taken on which $4 \mathrm{~cm} \times 4 \mathrm{~cm}$ size okra leaf bits were kept below which well moistened synthetic absorbent sponge covered by single layer of blotting paper placed for keeping okra leaf bits fresh and turgid for longer time.

Keen observations using high frequency electric binocular microscope were worked out and studied regarding critical changes been carried out during their life cycle stages. 


\section{Results and Discussion}

Taxanomic identification of okra mites (Tetranychus spp.)

For knowing taxonomical identification of mite spps., from the collected specimen initially under electric binocular microscope some selected mite specimen were picked on tiny hair brush point and placed in center of glass slide containing a drop of glycerol in such a way that all morphological characters necessary for identification can be clearly seen and covered with glass slide cover slip taking care that no air bubble was found during preparation of the slide. These slides were kept few days for drying and later under the technical guidance of expertise from AINPAA at GKVK, Bangalore a through morphological characterization studies were carried out which showed that the mite spps. identified was Tetranychus macfarlanei Baker and Pritchard (Plate 1).

\section{Biology of $T$. macfarlanei Baker and Pritchard on okra}

The taxonomically identified mite spps. $T$. macfarlanei on okra (Parbhani Kranti) was studied for its biology by maintaining the laboratory temperatures $\left(32^{\circ} \mathrm{C}\right)$ and relative humidity $(85 \pm 3 \%)$. Initially reared culture was used to obtain eggs of uniform age for which 50 males and 50 females were selected and released on cotton wades in petric plates and left for 6 hours. Later on male and female mites were removed leaving only fresh laid eggs which were assumed to be of similar age. The fresh laid eggs were placed individually on $4 \mathrm{~cm} \times 4 \mathrm{~cm}$ size okra leaf bit in petric plate making 20 different replications. Frequent and regular observations were been taken after every 3-6 hours to study detailed developmental periods of different stages which are presented as below (Table 1 and Plate 2).

\section{Egg}

Female laid eggs (Plate 3) on the lower surface of leaves alongwith webbings which were smooth, translucent white, spherical in shape just like a tiny drop of water. As the eggs moved towards maturity they gradually turned more brownish to creamy pinkish colour prior to hatching showing transparent and red eye spots at periphery area which corresponds to simple eyes of larvae. The period of incubation ranged between $3.58 \pm$ 0.31 days. The matured eggs were split vertically on one side of the cohesion from where larva emerged by pushing it apart with its legs leaving the egg shell intact on the leaf surface. The hatching percentage ranged from 86 to 94 per cent (Table 1).

\section{Larva}

The newly hatched larva (Plate 3) was hexapodous having somewhat spherical or slightly oval shape showing two prominent red simple eyes on the dorsal propodosomal region. After hatching the larva crawled for sometime and later settled at a place for feeding on the cell sap. Initially new born larva were creamy white which turned green and finally to dark green after initiation of feeding for some time with dark specks appearing dorsolaterally. The male larval period ranged from $1.38 \pm 0.19$ days and that of female larva the period ranged from $1.69 \pm$ 0.13 days.. In general, the larval period was shortest for male than female (Table 1).

\section{Nymphochrysalis (Quiescent stage I )}

At last period of larval development the larva ceased to feed and entered a quiescent stage by webbing or anchoring itself to a leaf surface for assuming a characteristic pose in which the anterior 2 pairs of legs were extending forward and kept close to each other and posterior legs were extended 
backwards and held close to the sides of opisthosoma. In case of male this quiescent stage lasted for $0.34 \pm 0.11$ days while in female it lasted for $0.44 \pm 0.17$ days, respectively (Table 1).

\section{Protonymph}

The newly emerged protonymph (Plate 4) was oval shaped and slightly bigger in size than the larva. It was easily distinguished due to the presence of four pairs of legs and gaining umber colour as feeding progressed with increase in size of dark specks on the dorsum as the time passed.

The protonymphal period of male occupied $1.59 \pm 0.32$ days and that of female occupied $1.79 \pm 0.42$ days, respectively (Table 1 ).

\section{Deutochrysalis (Quiescent stage II)}

A matured protonymph like larva moved towards second quiescent stage known as deutochrysalis (Plate 3 ) in which all activities of feeding were stopped and remained anchored to the leaf surface due to that body shrunk and decreased in size.

Deutochrysalis stages in male ranged from $0.56 \pm 0.20$ days and that of female the period of stage ranged from $0.59 \pm 0.22$ days, respectively (Table 1).

\section{Deutonymph}

The newly emerged deutonymph were caramine red in colour having larger and broder body size than the protonymph with quite noticeable sex determination period. The male deutonymph (Plate 3) was smaller in size and elongated with a growth period ranging from $0.97 \pm 0.26$ days whereas, the female deutonymph was broader and larger in size having a growth period ranging from 1.21 \pm 0.21 days, respectively (Table 1 ).

\section{Teleiochrysalis (Quiescent stage III)}

Teleiochrysalis known to be a matured deutonymph stage enters into a third quiescent stage (Plate 3) in which the body was shrunken and decreased in size having light carmine colour. The average teleiochrysalis period of male and female was $0.61 \pm 0.16$ and $0.92 \pm 0.23$ days, respectively (Table1).

\section{Total developmental period}

It was a duration from egg till emergence of an adult stage which was less in case of male (10.03 \pm 0.55 days) as compared to female (11.22 \pm 0.69 days) respectively (Table 1$)$.

\section{Adult}

The skin at later stage of teleiochrysalis was splitting dorsally from which adults emerged and started their activities immediately showing pronouned sexual dimorphism stages.

\section{Male}

The males (Plate 3) showed narrow body having two red spots corresponding to the simple eyes with reddish green body colour when newly emerged turning to pinkish as they get matured and distinctly pointed abdomen but were still smaller than the female. The first pair of legs was longer than the fourth pair while the second and third pairs were of similar size which helped for wondering or waiting over the quiescent female deutonymph i.e. teleiochrysalis stage. The male on an average lived for $16.97 \pm 0.26$ days (Table 1).

\section{Female}

The females (Plate 3) soon after emergence 
showed reddish bright colour which after feeding changed to carmine/ brick red with two red spots like simple eyes on the sides of dorsal propodosomal region. The female was found bigger than the male with a rounded and oval shaped abdomen and on an average lived for $19.39 \pm 0.13$ days (Table 1 ).

\section{Mating}

As males emerged little earlier than females they wandered on the leaf surface in search of a quiescent female deutonymph and when found, it placed the anterior pair of legs on female and waited for its emergence. There was an aggressive fighting been seen sometimes among three or four males themselves near the female by extending their chelicerae and pricking the other individuals. Also males were found helping the adult female to emerge out by pulling out the ecdysial skin of female by its two anterior pair of legs. When succeeded the male immediately slide underneath the female with its hysterosoma upturned, while the female raised its posterior abdominal region to accommodate the male for mating(Plate 3) and holding the female with front two pairs of legs during the process of coupling which lasted for about one to three minutes. Single male was observed to mate with several females, but a female usually mated only once soon after emergence. While older females were occasionally preferred by males for mating purpose.

Table.1 Biology of Tetranychus macfarlanei on okra at temperature $32^{\circ} \mathrm{C}$ and $\quad 85 \pm 3 \% \mathrm{RH}$ under laboratory conditions

\begin{tabular}{|c|c|c|}
\hline Growth Stage & Sex & $\begin{array}{c}\text { Developmental } \\
\text { period in days } \\
\text { (Mean } \pm \text { SD) }\end{array}$ \\
\hline Egg & - & $3.58 \pm 0.31$ \\
\hline \multirow{2}{*}{ Larva } & Male & $1.38 \pm 0.19$ \\
\cline { 2 - 3 } & Female & $1.69 \pm 0.13$ \\
\hline Nymphochrysalis & Male & $0.34 \pm 0.11$ \\
\cline { 2 - 3 } & Female & $0.44 \pm 0.17$ \\
\hline \multirow{2}{*}{ Protonymph } & Male & $1.59 \pm 0.32$ \\
\cline { 2 - 3 } & Female & $1.79 \pm 0.42$ \\
\hline \multirow{2}{*}{ Deutochrysalis } & Male & $0.56 \pm 0.20$ \\
\cline { 2 - 3 } & Female & $0.59 \pm 0.22$ \\
\hline \multirow{2}{*}{ Deutonymph } & Male & $0.97 \pm 0.26$ \\
\cline { 2 - 3 } & Female & $1.21 \pm 0.21$ \\
\hline \multirow{2}{*}{ Teleiochrysails } & Male & $0.61 \pm 0.16$ \\
\cline { 2 - 3 } & Female & $0.92 \pm 0.23$ \\
\hline \multirow{2}{*}{ Total } & Male & $10.03 \pm 0.55$ \\
\cline { 2 - 3 } Developmental & Female & $11.22 \pm 0.69$ \\
period & & \\
\hline
\end{tabular}


Table.2 Life history parameters of adults of Tetranychus macfarlanei on okra at temperature $32^{\circ}$ $\mathrm{C}$ and $85 \pm 3 \% \mathrm{RH}$ under laboratory conditions

\begin{tabular}{|c|c|c|}
\hline \multirow{2}{*}{ Period } & Sex & $\begin{array}{c}\text { Duration in Days } \\
\text { (Mean } \pm \text { SD) }\end{array}$ \\
\hline \multirow{2}{*}{ Pre oviposition } & Mated female & $1.59 \pm 0.28$ \\
\cline { 2 - 3 } & Unmated female & $1.14 \pm 0.36$ \\
\hline \multirow{2}{*}{ Oviposition } & Mated female & $15.83 \pm 0.16$ \\
\cline { 2 - 3 } & Unmated female & $17.92 \pm 0.82$ \\
\hline \multirow{2}{*}{ Post oviposition } & Mated female & $1.63 \pm 0.14$ \\
\cline { 2 - 3 } & Unmated female & $1.96 \pm 0.62$ \\
\hline \multirow{2}{*}{ Adult longevity } & Male & $16.97 \pm 0.26$ \\
\cline { 2 - 3 } & Female & $19.39 \pm 0.13$ \\
\hline \multirow{2}{*}{ Fecundity } & Mated female & $49.27 \pm 6.38$ \\
\cline { 2 - 3 } Male: Female & Unmated female & $22.16 \pm 7.14$ \\
\cline { 2 - 3 } Ratio & Mated female & $1: 9.6$ \\
\hline \multirow{2}{*}{$\begin{array}{c}\text { No of eggs } \\
\text { laid/day/ female }\end{array}$} & Unmated female & $1: 0$ \\
\hline \multirow{2}{*}{ Total life cycle } & Mnmated female & $2.95 \pm 0.67$ \\
\cline { 2 - 3 } & Male & $30.12 \pm 0.52$ \\
\hline
\end{tabular}

Plate.1 Supportive morphological characters for identification of Tetranychus macfarlanei Baker and Pritchard mite spps

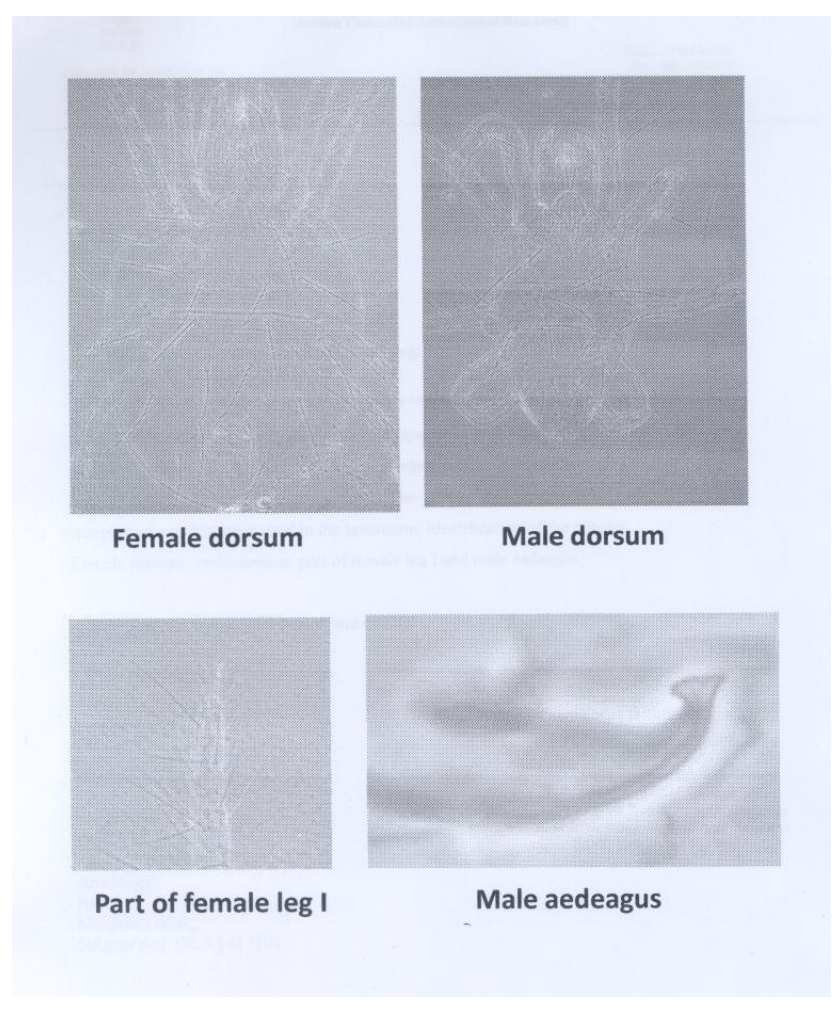


Plate.2 Maintenance of okra mite culture for taxanomic identification and knowing biology of mites (Tetranychus spp.)

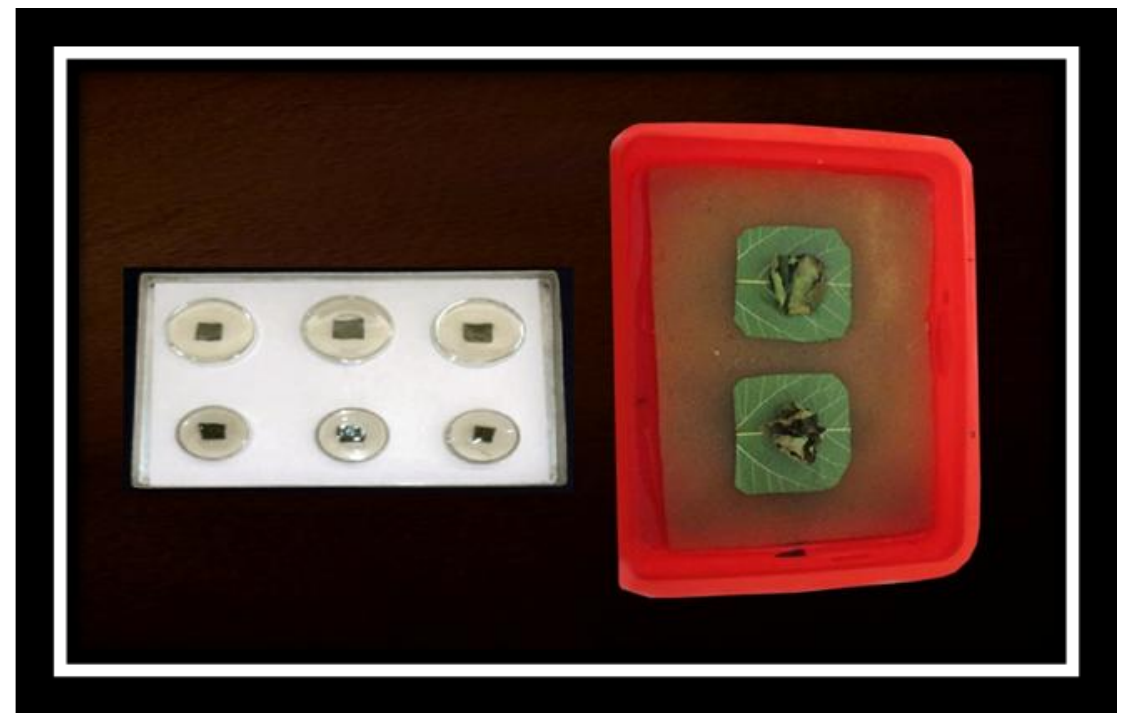

Plate.3 Life cycle of Tetranychus macfarlanei Baker and Pritchard mite spps

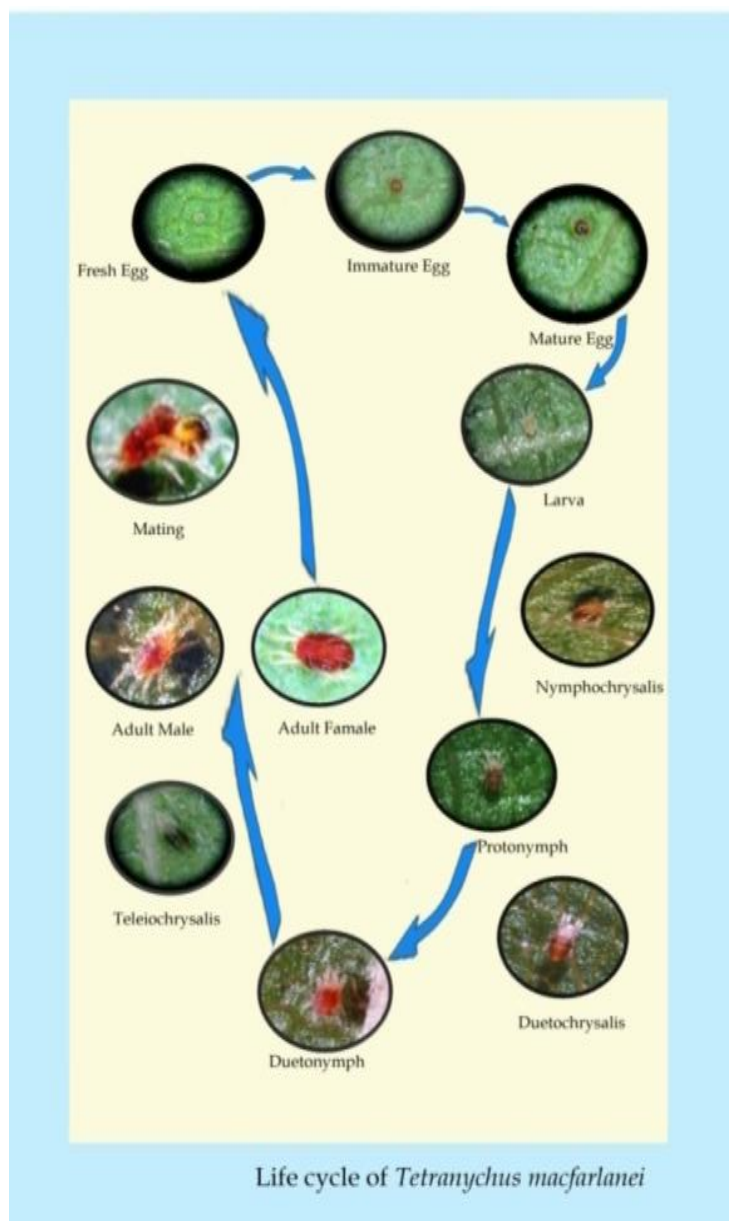




\section{Sex ratio}

It was observed that adults of mite spps. $T$. macfarlanei reproduced sexually and parthenogenetically. Sexually mated females produced both sexes with male to female ratio of 1: 9.6 whereas, unmated females produced only 100 per cent males.

\section{Pre oviposition period}

The mated and unmated female laid eggs only after a lapse of certain period which lasted for $1.59 \pm 0.28$ days in case mated female while it lasted for $1.14 \pm 0.36$ days in case of unmated females. As the females fertilized immediately after emergence the pre copulation period was very negligible in case of mated females (Table 2).

\section{Oviposition period}

The egg laying period of mated and unmated females lasted for somewhat longer period if been compared with its total developmental period. In case of mated females it took $15.83 \pm 0.16$ days for laying eggs whereas unmated females required a little longer time i.e., $17.92 \pm 0.82$ days respectively (Table 2 ).

\section{Fecundity}

During the total oviposition period, the mated female laid near about $49.27 \pm 6.38$ eggs while unmated female laid $22.16 \pm 7.14$ eggs. The daily egg production by mated female was nearby 2.95 \pm 0.67 eggs whereas unmated female was $1.12 \pm$ 0.52 eggs respectively (Table 2 ).

\section{Post oviposition period}

Post oviposition period in mated females lasted for $1.63 \pm 0.14$ days and for unmated females it lasted for $1.96 \pm 0.62$ days ( Table 2).

\section{Total life cycle}

From the above studies regarding the life cycle of mite spps. T. macfarlanei it was observed that total life cycle from egg stage till death of mite showed that the males completed life cycle earlier within $27.00 \pm 0.81$ days while females required
$30.61 \pm 0.82$ days to complete its life cycle (Table 2).

These results are in line with the works of Sharma (2010) and Kumar and Raghuraman (2013) who reported its biology on brinjal, whereas Thulsiram (1991) and Bhanderi (1991) recorded varying developmental periods which differed from present study may probably be due to change in species studied, hosts on which it was reared and climatic condition.

The female longevity lasted for about 19.39 days while, the male lived for a period of 16.97 days. The males emerged earlier and were found waiting near the female quiescent deutonymph. Both parthenogenetic and sexual type of reproduction was seen. Longer time was taken by unmated females to complete their pre oviposition, oviposition and post oviposition period as compared to mated females which was found somewhat similar to the findings of Patil (2005) and Shaw and Devroy (1995) while differed with the studies of Sejalia et al. (1993). In the present study the mated females laid more eggs than unmated ones, the results being which is in accordance with that of Singh et al (1996).

The total egg production by T. macfarlanei was 49.27 in mated females while unmated females laid 22.16 eggs. The results are comparable with the findings of Kumar and Raghuraman (2013) but differed with Rai et al (1995) and Singh et al. (1996). The higher fecundity of T. macfarlanei has been reported by Jose and Shah (1989), who observed 137 eggs per female on cotton. The male to female ratio observed was (1:9.6) contradictory with the studies of Singh et al. (1996). The per cent viability of eggs (86-94\%) was similar to that observed by Patil (2005) and Jose and Shah (1989).

In conclusion, as mites now a days are assuming a serious pest status due to their phytophagous nature, high reproductive potential and short life cycle which contributes for rapid resistance development to many acaricides often after a few applications (Cranham and Helle, 1985; Devine et al., 2001; Stumpf and Nauen, 2001). Hence to overcome this a new dimensional study was been undertaken to identify the spps. and work out 
biology of okra mites (Tetranychus spp.) which may surely help for their effective management.

\section{References}

Anonymous, 2013. Indian Horticultural Database 2013-14. National Horticultural Board, Ministry of Agriculture, Government of India.

Basu, K.H. and Ghosh, B.D.1943. Nutritional Status in Some Vegetables. Indian $J$. Medicinal Res., 31: 29-31.

Bhanderi, G. R. 1991. An Ecology of Tetranychus macfarlanei Baker and Pritchard (Acari : Tetranychidae) in Relation to Different Okra Cultivars and its Control. M.Sc.(Agri) Thesis, Gujarath Agricultural University, Navasari.

Jose, V. T. and Shah, A. H. 1989. Binomics of the Spider Mite, Tetranychus macfarlanei Injurious to Cotton in Gujarat, India. In: Progress in Acarology), Eds., Channabasavanna G. P. and Viraktamath, C. A., Oxford and IBH Publishing Co.Pvt. Ltd., New Delhi.

Kumar, D. and Raghuraman, M. 2013. Biology of Carmine Mite, (Tetranychus urticae koch) on Brinjal Leaf. Bioinfolet., 10(4C): 14201423.

Kumaran, N., Douressamy, S. and Ramaraju, K. 2007. Bioefficacy of Botanicals to Two Spotted Spider Mite, Tetranychus urticae (Acari: Tetranychidae) Infesting Okra (Abelmoschus esculentus L.). Pestology., 31(9): 43-49.

Mondel, M. and N. Ara. 2006. Biology and Fecundity of the Two Spotted Spider Mite, Tetranychus urticae Koch. (Acari: Tetranychidae) Under Laboratory Conditions. J. Life Earth Sci., 1: 43-47.

Patil, R. S. 2005. Investigations on Mite Pests of Solanaceous Vegetable with Special
Reference to Brinjal. P.hd. (Agri.) Thesis, University of Agricultural Sciences, Dharwad.

Rai, A. B., Sejalia, A. S., Patel, C. B. and Kumar, S. 1995. The Rate of Natural Increase of Red Spider Mite when Reared on Okra. Gujarat Agril. Uni. Res. J., 21(1): 130136.

Sarkar, P.K., Mukherjee, A.B. and Ghosh, J. 1996. Assessment of Loss of Bhendi Against Red Spider Mite. Env. Eco., 14(2): 480-481.

Sejalia, A. S., Rai, A. B., Patel, C. B. and Radadai, G. G. 1993. On the Biological Aspects of Tetranychus macfarlanei (Acari : Tetranychidae) Infesting Okra (Abelmoschus esculentus) in South Gujarat. GAU Res. J., 19: 32-37.

Sharma, A. S. R. 2010. Seasonal Incidence and Management of Brinjal Mite, Tetranychus spp. P.hd. (Agri.) Thesis, University of Agricultural Sciences, Dharwad.

Shaw, K. K. and Devroy, T. C. 1995. Biology of Vegetable Red Spider Mite, Tetranychus neocaledonicus Andre (Acarina : Tetranychidae) on Brinjal. J. Agril. Sci. Soc. North East India., 8: 6-9.

Singh Rishi Kumar, S. K. Malik and Naveen Aggarwal V. S. 1996. Biological Studies of Red Spider Mite, Tetranychus cinnabarinus (Boisduval) on Okra. Ann. Agril. Res., 17(1): 60-63.

Srinivasa, N. and Sugeetha, G. 1999. Bioeffectiveness of Certain Botanical and Synthetic Pesticides Against Okra Spider Mite Tetranychus macfarlaeni. J. Acarol., 15(1\&2): 1-5.

Thulsiram. 1991. Binomics and Chemical Control of Tetranychus macfarlanei on Cotton. M.Sc. (Agri.) Thesis, University of Agricultural Sciences, Dharwad.

\section{How to cite this article:}

Jadhav, Y.T., B.B. Bhosale and Barkade, D.P. 2017. Study on Identification and Biology of Okra Mites sp. Int.J.Curr.Microbiol.App.Sci. 6(3): 2538-2546. doi: https://doi.org/10.20546/ijcmas.2017.603.287 